Journal of Teacher Education for Sustainability, vol. 21, no. 2, pp. 17-26, 2019

\title{
The Effect of Early Childhood Education and Care Services in Latvia
}

\author{
Katrīne Kūkoja \\ Vidzeme University of Applied Sciences, Valmiera, Latvia
}

\begin{abstract}
The growing number of studies stresses the importance of social investment at an early age by showing that social investment at this period has the highest returns in human capital. The main instrument of social investment at an early age is high quality early childhood education and care services. The aim of the research was to identify whether the first signs of social investment return could be observed in Latvia, since statistic data showed that there was an expansion of early childhood education and care services over the last decades, especially for children until obligatory pre-school age. Research results showed that positive connection could be observed between pre-school attendance rate and fertility rate, female and overall employment rate, average earning, etc. However, no connection could be observed when it came to education outcomes in the short term. The author recommends conducting more research regarding service quality and investment return in the future.
\end{abstract}

Key words: child development, early childhood education and care services, social investment return, women employment

\section{Introduction}

Social investment policies are becoming increasingly topical at the national and European levels, especially when it comes to importance of social investments in early childhood. The main instrument of social investment in this period of life is qualitative and available childhood education and care services (hereafter - ECEC services). As we can see in Figure 1, previous studies show that investments made in early childhood have the highest return in human capital. Both the Latvian and European Union (hereafter - EU) planning documents have stressed importance of social investment in early childhood. One of the policy priorities defined by both the European Commission (hereafter - EC) and the European Parliament (hereafter - EP) in order to meet the Europe 2020 targets is to "ensure universal provision of ECEC" (EC, 2011; EP, 2011). Meanwhile the Sustainable Development Strategy of Latvia until 2030 stresses that particular attention should be paid to the quality and availability of pre-school education - both because creative personality is forming at an early age and maximum and active involvement of parents in the labor market increases the necessity to find national solutions also at this stage of education (Saeima of the Republic of Latvia, 2010). 


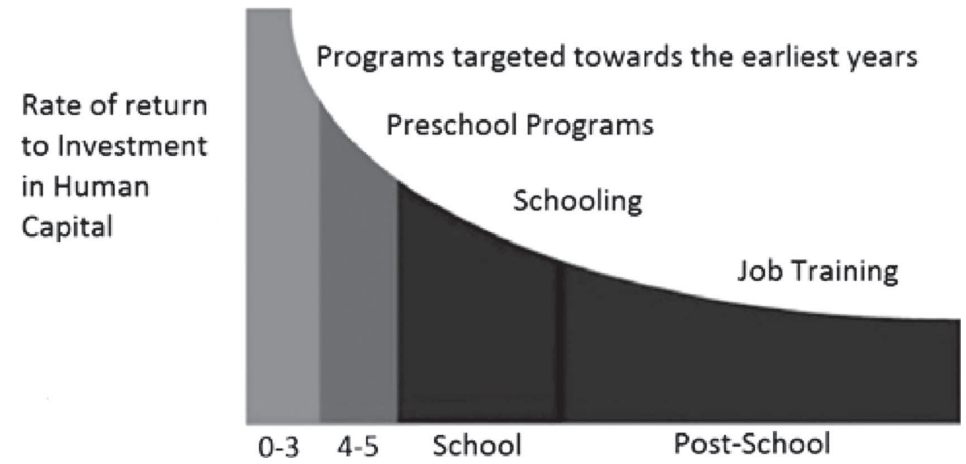

Figure 1. Return to a dollar invested at different levels of education (Heckman, 2008)

Previous studies show that successful implementation of social investment at an early age gives benefits both at the society and individual levels (Morel, Palier, \& Palme, 2012). The effect of social investment in this period of time can be observed in many areas of life both in the long and short term (see Figure 2).

Education outcomes: an increase in educational attainment results; improved cognitive outcomes; higher school completion and graduation rates; reductions in the need for school remedial educational services, etc.

Social economic outcomes: higher fertility rates and increased female workforce participation, increased equality in society, etc.

Increased exchequer returns: spill-over effect of ECEC related to higher tax returns due to higher labor participation and improved earnings; increase in lifetime earnings, compensation, and government tax revenues, etc.
Long-term economic outcomes:

increased earnings and labor-force participation; lower welfare dependency later in life, etc.

\section{Improved health, social well-being and reduced welfare dependency: reduction in the occurrences of child maltreatment and neglect, reduced teen pregnancy rates, reduction in expenditures for the child welfare system, etc.}

\section{Reduced crime rates:}

reduction of criminal justice system expenditures for youth and adult crime; reduction of expenditures to victims of juvenile and adult crime, decrease in crime rate, etc.

Figure 2. Social investment return matrix (Heckman, 2008; Jacinta \& Jacinta, 2015; Reynolds et al., 2011; EACEA \& Eurydice, 2009; Havnes \& Mogstad, 2011; Belle, 2016; Morel, Palier, \& Palme, 2012; Rajevska, 2018; Campbell et al., 2014).

Research conducted in Norway in 2016 showed that universally accessible childcare had large positive effects on education and labor market attachment, as well as welfare 
dependency. The study showed that additional 17,500 childcare places produced 6,200 years of education. Furthermore, children exposed to childcare delayed child bearing and family formation as adults. Norway subsample analysis indicated that most of the effect on labor market attachment and earnings was related to girls. This suggests that good access to subsidized childcare may level the playing field by closing the gender wage gap as well (Havnes \& Mogstad, 2011).

Other research conducted by Stanford University representatives (the USA) in 2008 showed that for disadvantaged children residing in small towns and rural areas universal childcare availability increased both reading and mathematics test scores at fourth grade as well as the probability of students being on-grade for their age. Research results showed that the first signs of social investment return (short-term return) could be absorbed already in elementary schools (Fitzpatrick, 2008).

As we can see from the description above, a number of studies provide strong evidence that educational programs oriented towards sustainability can contribute to well-being of individuals and society (Salite, 2009; Salite et al., 2018; Ülavere, 2017; Veisson \& Kabaday, 2018).

However, there is a lack of empirical research on social investment returns in Europe, since most of these studies have been conducted in the USA. Almost all current data on the long-term economic outcomes of the ECEC are results of three large studies conducted in the USA: the Perry High/Scope (1960s), the Abecedarian (1970s) and the Chicago Child-Parent study (1960s) (Belle, 2011).

It is important to study social investment tendencies and returns in Latvia in order to determine if investments made until now have already had some return, and if not what to do to reach the full potential of investments. Previously, social investment returns have not been researched in Latvia.

The aim of the research was to identify if the first signs of social investment return could be already observed in Latvia, since statistic data showed that there was an expansion of ECEC service attendance rate over the last decades in Latvia, especially for children until obligatory pre-school age - until age of 4 (including).

To achieve the aim of the research, the author analyzed whether or not positive connections could be observed between the ECEC service attendance rate in Latvia and indicators that in the previous studies were positively connected with the increase in the ECEC service attendance rate. Nine indicators were chosen randomly for this case study: educational attainment results ( $3^{\text {rd }}$ grade national test results), school graduation rate, average earning, teen pregnancy rate, fertility rate, female workforce participation rate, overall labor-force participation rate, as well as administrative crime rate in Latvia.

\section{Methods and Materials}

To reach the aim of the study, the analysis of policy documents and previous studies was carried out, as well as the analysis of publicly available statistic data about the ECEC service attendance rate and the chosen indicators. SPSS software was used for data editing, analysis and correlation determination.

Statistic data were analyzed in the period of 2010-2017, with exceptions in the case of high school graduation rate (2011-2017) and third graders' test results in math and languages (2012-2017), due to the lack of open access data available on these topics. 
One-Sample Kolmogorov-Smirnov Test was used to analyze the chosen indicators and the ECEC service attendance rate in the reporting period in order to determine whether data could be used for the purpose of analysis. Test results confirmed that the collected data were valid and usable in the research.

To get a deeper understanding of the research results that were related to educational outcomes, $1^{\text {st }}$ grade teacher pilot-surveys in two elementary schools were carried out 14 secondary school teachers were surveyed in two Valmiera elementary schools. Surveyed teachers had working experience of $18-36$ years as $1^{\text {st }}-4^{\text {th }}$ grade teachers.

\section{Tendencies of the ECEC in Latvia}

Since 2001, the Education Law stipulates that pre-school education is mandatory in Latvia from age of 5, but since 2013 the same law states that municipalities have the responsibility to provide a place in the ECEC institution to all children from age of one and a half. To ensure that all children can receive ECEC services from one and a half years of age, the Education Law stipulated that private ECEC institutions and babysitting services were co-funded at the national level until 2016, since public ECEC institutions could not provide the education service for all children in this age group (Saeima of the Republic of Latvia, 1998; Saeima of the Republic of Latvia, 2013).

These and other initiatives have improved the ECEC service attendance rate in Latvia significantly. During the past decades, there has been an increase in the ECEC service attendance rate in Latvia, especially when we analyze the data of children before the obligatory pre-school age - until age of 4 (including). The number of children in the ECEC institutions increased from 61759 in 2000 to 82169 in 2008 and to 96626 in 2017. Over the last 17 years, the number of children in the ECEC institutions increased by $56.5 \%$ (WEB (a)), while the overall birth rate coefficient (number of births per 1000 inhabitants) in Latvia had a tendency to likely change. If in 2000 the overall birth rate coefficient was 8.6 children per 1000 inhabitants, then in 2008 it reached 11.2, and in 2017 it already decreased to 10.7 children per 1000 inhabitants in Latvia (see Figure 3).

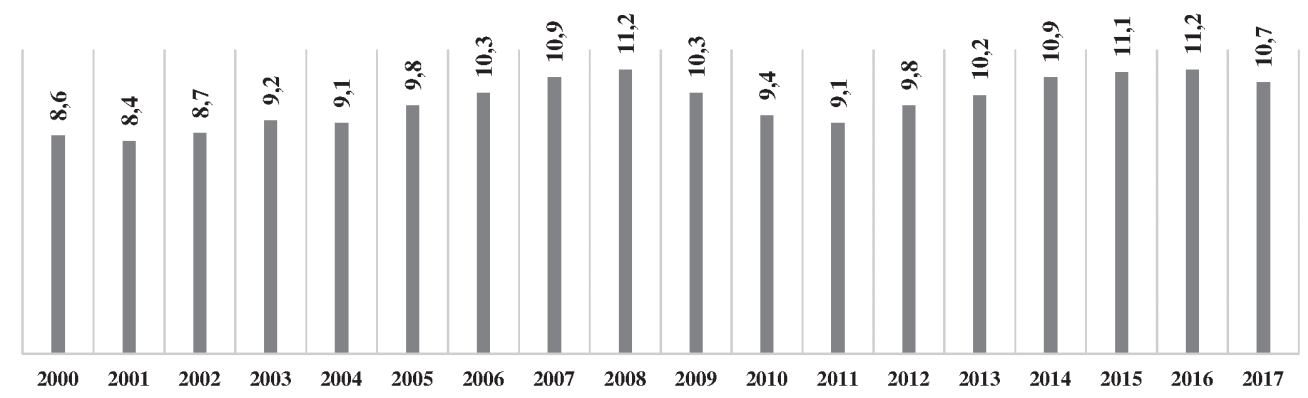

Figure 3. Overall birth rate per 1000 inhabitants in Latvia, 2000-2017. Source: WEB (f)

As we can see in Figure 4, while the number of children from age of 5 until age of 6 in ECEC institutions had a tendency to stay more or less at the same level in last decade (with a tendency to decrease since 2013), the number of children until age of 4 (including) had a tenancy to increase in the ECEC institutions (WEB (b)). 


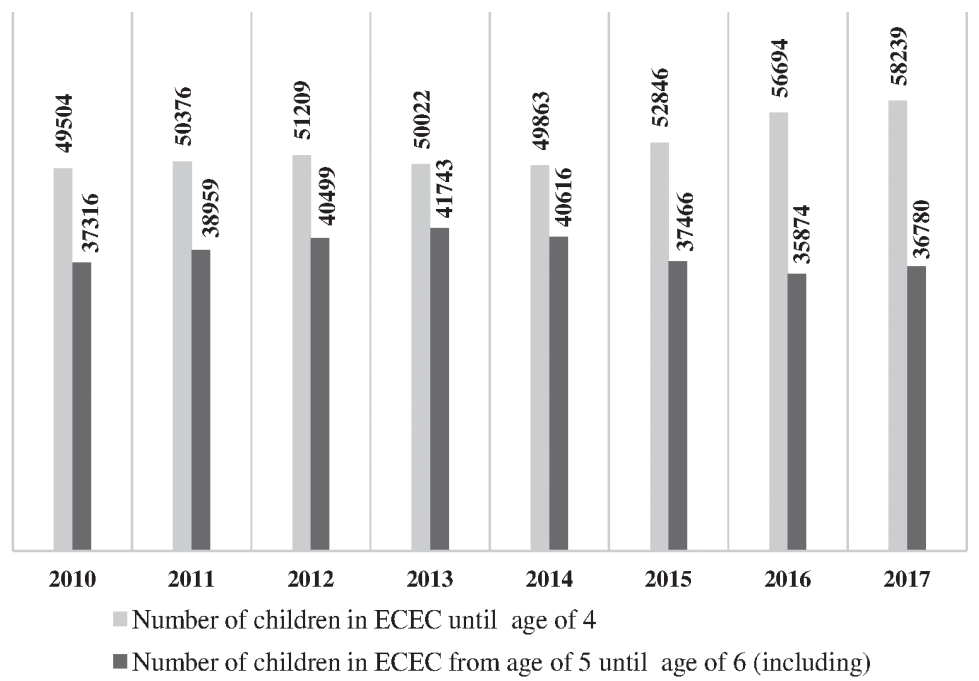

Figure 4. The number of children in ECEC by age, 2010-2017. Source: WEB (b)

Figure 5 shows that percentage of children until age of 4 attending ECEC services increased from $44.43 \%$ in 2010 to $54.44 \%$ in 2017 (WEB (c); WEB (d)). However, the percentage of children attending the ECEC institutions aged between 4 and the age of starting compulsory education (age of 7) is still significantly higher than at an earlier age. In 2016, $95.5 \%$ of children aged between 4 and the age of starting compulsory education attended ECEC services, while only $54.71 \%$ of children until age of 4 (including) attended ECEC services. Furthermore, the Latvian ECEC service attendance rate of children aged between 4 and the age of starting compulsory education is higher than in the neighboring countries, for example, in Estonia it is $92.6 \%$ and in Lithuania $91.4 \%$, and the EU average is $95.3 \%$ (WEB (e)).

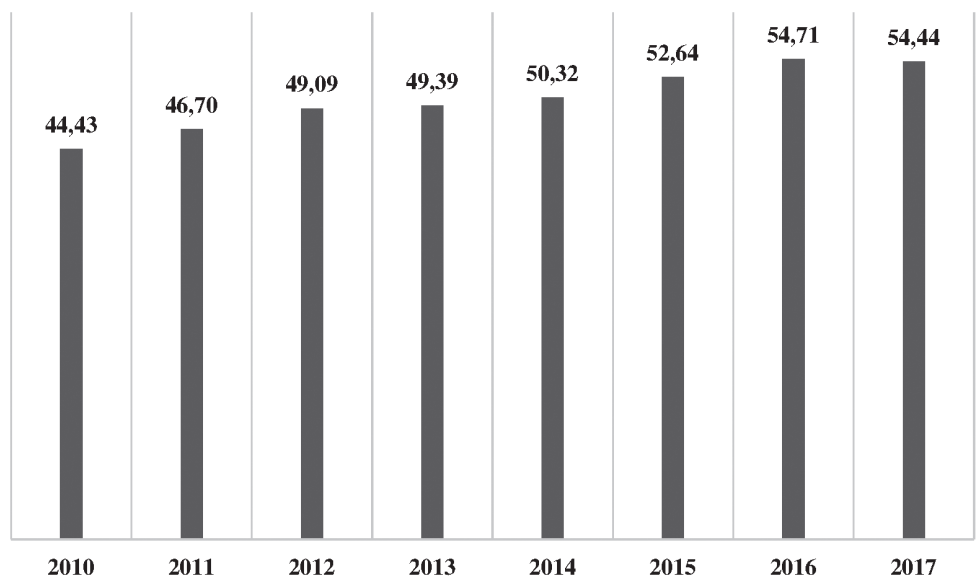

Figure 5. Percentage (\%) of children until age of four attending ECEC services in Latvia. Source: WEB (c); WEB (d) 


\section{Results}

Research results show that over the past years high positive correlation can be observed when it comes to the ECEC service attendance rate and the following indicators: fertility rate (0.879), women employment (0.981), overall employment (0.980) and average earning (0.955), indicating that when the ECEC service attendance rate increases, these indicators also have a tendency to increase. Weaker, but still statistically relevant positive correlation can be observed when we look at the high school graduation rate (0.703).

Regarding the teen pregnancy, results showed that during the period of 20102017 high negative correlation could be observed (-0.976), indicating that when the ECEC attendance rate increased, the teen pregnancy rate had a tendency to decrease in Latvia. Weaker, but still statistically relevant negative correlation can be observed when we look at the rate of administrative crime level in Latvia (-0.786).

However, research results showed that no correlation could be observed between the ECEC service attendance rate and the educational attainment indicators - average state examination results of third graders in mathematics $(-0.110)$ and learning language (0.111), indicating that in the reporting period statistically relevant connection did not exist between these indicators (see Table 1).

As mentioned above, to get a deeper understanding of the results of short-term education attainment tendencies in Latvia, teachers' pilot-surveys in two elementary schools of Valmiera were carried out. The survey results showed that one of the main reasons for this situation was the fact that children came to school inadequately and unevenly prepared (for example, some students could not read) indicating some ECEC quality problems.

Some of the other responses mentioned in surveys regarding tendencies of average state examination results of third graders in mathematics $(-0.110)$ and learning language are the following:

- The number of students in class is too high and the proportion of younger pupils has increased in recent years. More children are starting school at age of 6 and it pulls the average mark down;

- Many children have behavioral and learning disturbance problems, as well as lack of motivation. The main reason is the fact that children start school earlier;

- There is a continuous change, which results in pupils and teachers being overloaded with "unnecessary" things, for example, over time there has been an increase in requirements imposed on children who start attending school now students have to know how to read before starting school;

- Each year the state examination differs in the difficulty level. 
Table 1

Correlation Results between ECEC Attendance Rate and the Chosen Indicators in Latvia

\begin{tabular}{|c|c|c|}
\hline & & $\begin{array}{c}\text { ECEC attendance rate for children } \\
\text { until age of } 4\end{array}$ \\
\hline \multirow[t]{3}{*}{ Fertility rate - TOTAL } & Pearson Correlation & $.879^{* *}$ \\
\hline & Sig. (2-tailed) & .004 \\
\hline & $\mathrm{N}$ & 8 \\
\hline \multirow[t]{3}{*}{ Women employment } & Pearson Correlation & $.981^{* * *}$ \\
\hline & Sig. (2-tailed) & .000 \\
\hline & $\mathrm{N}$ & 8 \\
\hline \multirow[t]{3}{*}{ Employment rate - TOTAL } & Pearson Correlation & $.980^{* *}$ \\
\hline & Sig. (2-tailed) & .000 \\
\hline & $\mathrm{N}$ & 8 \\
\hline \multirow[t]{3}{*}{ Average salary } & Pearson Correlation & $.955^{* *}$ \\
\hline & Sig. (2-tailed) & .000 \\
\hline & $\mathrm{N}$ & 8 \\
\hline \multirow[t]{3}{*}{ Birth rate until age 19} & Pearson Correlation & $-.976^{* *}$ \\
\hline & Sig. (2-tailed) & .000 \\
\hline & $\mathrm{N}$ & 8 \\
\hline \multirow{3}{*}{$\begin{array}{l}\text { Number of administrative } \\
\text { violations }\end{array}$} & Pearson Correlation & $-.786^{*}$ \\
\hline & Sig. (2-tailed) & .021 \\
\hline & $\mathrm{N}$ & 8 \\
\hline \multirow{3}{*}{$\begin{array}{l}\text { Average state examination } \\
\text { results of third graders in } \\
\text { mathematics }\end{array}$} & Pearson Correlation & -.110 \\
\hline & Sig. (2-tailed) & .835 \\
\hline & $\mathrm{N}$ & 6 \\
\hline \multirow{3}{*}{$\begin{array}{l}\text { Average state examination } \\
\text { results of third graders in } \\
\text { learning language }\end{array}$} & Pearson Correlation & .111 \\
\hline & Sig. (2-tailed) & .835 \\
\hline & $\mathrm{N}$ & 6 \\
\hline \multirow{3}{*}{$\begin{array}{l}\text { High school graduation rate } \\
(\%)\end{array}$} & Pearson Correlation & .703 \\
\hline & Sig. (2-tailed) & .078 \\
\hline & $\mathrm{N}$ & 7 \\
\hline
\end{tabular}

* Correlation is significant at the 0.05 level (2-tailed).

$*$ C Correlation is significant at the 0.01 level (2-tailed).

\section{Discussion and Conclusions}

In the recent decade, there has been an increase in social investment at an early age in Latvia that has led to a higher ECEC service attendance rate, especially for children until obligatory pre-school age - age of 4 (including). If in 2010, 44.3\% of children in this age group attended the ECEC services, in 2017 the number of children increased to $54.4 \%$.

Statistic data show that when it comes to older children, the ECEC service attendance rate is relatively high in Latvia - above EU average rate and ECEC service attendance rate in the neighboring Baltic countries.

Data analysis shows that positive correlation can be observed between the ECEC service attendance rate and the following indicators - an increase in the fertility rate, 
female employment rate and overall employment rate, average earning rate, high school graduation rate, decrease in teen pregnancy rate and administrative crime rate.

However, despite the fact that literature suggests that the social investment effect on educational attainment is one of the results that can be observed at the earliest (short-term return), the research has shown that it is not true in this case study. No statistically relevant correlation could be observed when it came to average state examination results of third graders in mathematics and learning language, and this might raise concerns about the ECEC service quality, since for social investment to reach its full potential ECEC services should not only be available, but also qualitative. Pilot-surveys with the $1^{\text {st }}$ grade teachers confirmed this concern, since most teachers suggested that one of the reasons why this kind of situation might occur was due to the quality problems in ECEC institutions - inadequately and unevenly trained children coming to school. Further studies in this field should be carried out.

Based on the research results, the author concludes that the ECEC service attendance rate can be one of the factors that has positively influenced the above-mentioned indicators and the first signs of social investment return can be observed in Latvia, but further studies regarding this topic should be carried out in the future.

\section{Acknowledgements}

The author would like to express her gratitude to the Institute of Social, Economic and Humanities Research of Vidzeme University of Applied Sciences for provided financial support for conducting the research.

\section{References}

Belle, J. (2016). Early Childhood Education and Care (ECEC) and its long-term effects on educational and labour market outcomes. Retrieved from https://www.rand.org/ pubs/research_reports/RR1667.html

Campbell, F., Conti, G., Heckman, J. J., Moon, S. H., Pinto, R., Pungello, E., \& Pan, Y. (2014). Early childhood investments substantially boost adult health. Retrieved from http://science.sciencemag.org/content/343/6178/1478.long

EACEA, Eurydice. (2009). Early childhood education and care in Europe: Tackling social and cultural inequalities. Retrieved from https://publications.europa.eu/ en/publication-detail/-/publication/83f56fb3-62f0-440e-b646-c782f2abef18/ language-lv

EC (2011). Early childhood education and care: Providing all our children the world of tomorrow. Retrieved from https://www.rand.org/pubs/research_reports/RR1667.html

EP (2011). Resolution of 12 May 2011 on Early Years Learning in the European Union. Retrieved from https://eur-lex.europa.eu/legal-content/EN/TXT/PDF/?uri=CELEX: 52011IP0231\& from=EN

Fitzpatrick, M. D. (2008). Starting school at four: The effect of universal pre-kindergarten on children's academic achievement. Retrieved from http://www-siepr.stanford.edu/ Papers/pdf/08-05.pdf

Havnes, T., \& Mogstad, M. (2011). No child left behind universal child care and children's long-run outcomes. Retrieved from https://www.ssb.no/a/publikasjoner/ pdf/DP/dp582.pdf 
Heckman, J. J. (2008). Schools, skills, and synapses. Retrieved from https://www.nber. org/papers/w14064

Jacinta, R. M., \& Jacinta, K. S. (2015). Impact of early childhood education on pupils' learning in primary schools in Kenya. Retrieved from http://www.macrothink.org/ journal/index.php/gjes/article/view/7686

Morel, N., Palier, B., \& Palme, J. (2012). Towards a social investment welfare state?: Ideas, policies and challenges. The Policy press, Great Britain.

Rajevska F. (Ed.). (2018). Turns of social policy transformation in post-crisis years. National research program EKOSOC_LV, project 5.2.6. LU, RSU, ViA, Riga, 2018.

Reynolds, A. J., Temple, J. A., White, B. A., Ou, S. R., \& Robertson, D. L. (2011). Age-26 cost-benefit analysis of the child-parent center early education program. Retrieved from https://doi.org/10.1111/j.1467-8624.2010.01563.x

Saeima of the Republic of Latvia. (2010). Sustainable development strategy of Latvia until 2030. Retrieved from http://www.varam.gov.lv/in_site/tools/download.php? file=files/text/dokumenti/pol_doc//LIAS_2030_parluks_en.pdf

Saeima of the Republic of Latvia. (1998). Education Law. Retrieved from https://likumi. lv/doc.php?id=50759

Saeima of the Republic of Latvia. (2013). Amendments in Education Law. Retrieved from https://likumi.lv/ta/id/258475-grozijumi-izglitibas-likuma

Salìte, I. (2009). Educational action research for sustainability: Constructing a vision for the future in teacher education. Journal of Teacher Education for Sustainability, 10(1), 5-16. doi: https://doi.org/10.2478/v10099-009-0021-6

Salīte, I., Drelinga, E., Iliško, Dz., Oḷehnoviča, E., \& Zariṇa, S. (2016). Sustainability from the transdisciplinary perspective: An action research strategy for continuing education program development. Journal of Teacher Education for Sustainability, 18(2), 135-152. doi: https://doi.org/10.1515/jtes-2016-0020

Ülavere, P. (2017). Value education in Estonian preschool child care institutions. Journal of Teacher Education for Sustainability, 19(1), 129-146. doi: https://doi.org/ 10.1515/jtes-2017-0009

Veisson, M., \& Kabadayi, A. (2018). Exploring the preschool teachers' views on professionalism, quality of education and sustainability: International study in Estonia and Turkey. Journal of Teacher Education for Sustainability, 20(2), 5-18. doi: https://doi.org/10.2478/jtes-2018-0011

WEB (a). Statistika [Statistics]. Retrieved from https://www.csb.gov.lv/lv/statistika/db

WEB (b). Sociālie procesi [Social processes]. Retrieved from http://data1.csb.gov.lv/ pxweb/lv/sociala/sociala__izgl__pirmsskolas/?tablelist=true\&rxid=a39c3f49-e95e43e7-b4f0-dce111b48ba1

WEB (c). Iedzīvotājus raksturojošie rādìtāji [Indicators of population characteristics]. Retrieved from http://data1.csb.gov.lv/pxweb/lv/sociala/sociala_izgl_pirmsskolas/ ?tablelist=true\&rxid=a39c3f49-e95e-43e7-b4f0-dce111b48ba1

WEB (d). Izglitība-pirmsskolas [Preschool education]. Retrieved from http://data1.csb. gov.lv/pxweb/lv/sociala/sociala__izgl__pirmsskolas/?tablelist=true\&rxid=a39c3f49e95e-43e7-b4f0-dce111b48ba1

WEB (e). Early childhood and primary education statistics. Retrieved from https://ec. europa.eu/eurostat/statistics-explained/index.php/Early_childhood_and_primary_ education_statistics 
WEB (f). Dzimstība-dzimstības vispārīgais koeficients reǵionos, republikas pilsētās un novados (uz 1000 iedzivotāju) [Overall birth ratio in regions, cities of Republic and regional communities (per 1000 inhabitants)]. Retrived from http://data1.csb. gov.lv/pxweb/lv/iedz/iedz_dzimst/IDG140.px/?rxid=d8284c56-0641-451c-8b70b6297b58f464

Correspondence concerning this paper should be addressed to Katrīne Kūkoja, Research Assistant, Institute of social, economic and humanities research, Vidzeme University of Applied Sciences, Cēsu iela 4, Valmiera, LV-4201, Latvia. Email: katrine.kukoja@va.lv 